\title{
Risks and Benefits of Global Warming and the Loss of Mountain Glaciers and Ice Patches to Archeological, Paleoclimate, and Paleoecology Resources
}

\author{
Robert H. Brunswig
}

Department of Anthropology

University of Northern Colorado

Greeley, Colorado 80639 USA, email: robert.brunswig@unco.edu

\begin{abstract}
Scientific documentation of global warming, despite disagreement on its ultimate causes, includes measurable rises in sea levels, more frequently stronger and more violent weather patterns, and accelerating melting of Arctic and Antarctic ice sheets, long-existing glaciers, and "permanent" snow fields. In recent years, there have been numerous discoveries of ancient human, animal, and plant remains melted from long-frozen snow and ice, finds which recently led to development of a new subfield of archaeology known as ice patch or glacial archaeology. Ice patch organic remains, once exposed, are subject to rapid deterioration and destruction. Both cultural and natural remains, if identified and collected prior to extended surface exposure can provide extraordinary evidence about past societies, climates, and ecosystems. This article provides a short background and discussion on the nature and history of the emerging science of glacier/ice patch archaeology and describes results of an on-going study in the United States' southern Rocky Mountains where ice patch evidence for climate change is integrated with more traditional paleoclimate and archaeological research to reconstruct several millennia of cultural, climate, and ecological landscape evolution.
\end{abstract}

Key words: Ice patch archaeology, global warming, Rocky Mountain National Park.

\section{Introduction}

The long-term effects of global climate change on ecosystems, ocean levels, and the world economic system are a subject of intense debate by scientists, politicians, and ordinary citizens (National Academy of Sciences 2014). There remains little doubt global warming is accelerating and Earth's Arctic and Antarctic ice sheets and the vast majority of mountain glaciers, many having remained in existence since the last major ice age despite intervening, periodic warm climate period, will likely disappear by the end of the Twenty-First Century (cf., Radic \& Hock 2011; Jacob et al. 2012; Khan et al. 2014). The impact of warming on the world's cultural (archaeological and historical) resources will be severe, ranging from destruction through flooding to rising water tables and more frequent, devasta- ting storms in coastal and inland regions. Another climate change effect, the central topic of this article, is the melting of mountain glaciers and permanent snowfields (ice patches) and exposure of long-buried, frozen plant, animal, and archaeological remains. Uncovering of those remains provides unparalleled opportunities to better understand longterm climate change effects in regions with ice patches and glaciers and past human adaptations to those changes.

Although natural and cultural organic materials have been recovered from melting glaciers and ice patches in the more distant past, their growing appearance in the late $20^{\text {th }}$ and $21^{\text {st }}$ centuries, due to accumulating effects of global warming, is noteworthy (Keen 2008). And, within the past decade, a new archaeological specialization, ice patch archaeology, also often referred to as glacier archaeology, has evolved to more formally and systematically dis- 
cover and analyze cultural and natural materials recovered from ice and snow formations (Andrews \& MacKay 2012; Reckin 2013; Rogers et al. 2014). It is the goal of this article to briefly summarize the benefits and often unique forms of evidence offered by ice patch archaeology and emphasize the advantages of approaching ice patch research within the frameworks of holistic, multi-disciplinary research agendas. In support of that goal, a case study of high altitude archaeological and paleoclimate-paleoecology research in North America's Rocky Mountains National Park, conducted by the author and colleagues at the University of Northern Colorado, is presented

\section{Past and Recent Glacier and Ice Patch Archaeology Research}

Although knowledge of ancient and recent glacial and ice patch sourced organic materials has existed for many years (Keen 2008), general awareness of the phenomenon dramatically grew with emergence of a mummified Neolithic-Copper Age body, Ötzi the Ice Man, from a Tyrolean Alp ice patch on the Austrian-Italian border in September, 1991 (Spindler 1993, 1995). Discovery of the frozen Ötzi mummy, it can be argued, was a modern signature event leading to the development of modern ice patch archaeology. Over the past quarter century of research on the mummy and cultural (organic and inorganic) artifacts associated with it, wide ranging of interdisciplinary studies have revealed his chronology (a Late Neolithic-Copper Age radiocarbon date of ca. $2550 \mathrm{cal}{ }^{14} \mathrm{C}$ cal BC) (Kutschera 1994), his last meal (Rollo et al. 2002), individual genetic type (previously undocumented in European populations) (Ermini et al. 2008), evidence of a violent death (from an arrow wound and skull fracture) (zur Nedden et al. 1994), and reconstruction of his era's paleoecology (Bortenschlager \& Oeggl 2000; Oeggl 2009) and transition into climatic cooling (Magny \& Haas 2004), the latter partly responsible for the mummy's preservation. A recent article even proposes Ötzi may have been killed elsewhere and his body temporarily preserved and transported to his high mountain find-location as a form of ritual activity (Vanzetti et al. 2010). Elsewhere in Europe, melting ice patches and glaciers in Norway have exposed a Late Iron Age ( $3^{\text {rd }}-4^{\text {th }}$ Century AD) woven wool tunic (Vedeler \& Jorgensen 2013) and a Neolithic bow and arrows (Callanan 2012, 2013). And, in the Swiss Alps pass of Schnidejoch, organic and inorganic artifacts from multiple periods (Neolithic, Bronze, Roman, and Middle Age) have been recovered from melting glacier ice fields (Suter et al. 2005; Grosjean et al. 2007; Hafner 2012).

Ice patch archaeology in North America has grown incrementally since the mid-2000s. Numerous discoveries have resulted from 2006 to the present as part of a largescale research program, the Northwest Territories Ice Patch
Study, focused on northwest Canada's arctic and near-arctic regions (Andrews et al. 2009, 2012a, 2012b; Andrews \& MacKay 2012). Geological studies have shown that many Northwest Territories ice patches have been stable for as long ago as 8000 years, but have begun to melt in recent years, exposing cultural artifacts and animal remains (Meulendyk et al. 2012). Analysis of intact and melting margins of Canadian ice patches have shown that prehistoric caribou used them for thousands of years for avoiding summer insects and warm temperatures (Ion \& Kershaw 1989; Kuzyk et al. 1999). Those analyses also show that ice-embedded hunting weapons and butchered animal remains document the use of ice patches as native peoples' hunting locations for eight millennia (Hare et al. 2004, 2012). Evidence from wooden hunting tools, such as 1000 year old arrows, and leather foot-wear, butchered bone, and animal dung (mainly caribou and bison) have provide new information on prehistoric technology, subsistence, paleoecology and paleoclimate (cf., Farnell et al. 2004; Andrews et al. 2009; Alix et al. 2012; Galloway et al. 2012; Hare et al. 2012).

South of the Canadian border in the western American central and southern Rocky Mountains, ice patch archaeology has also been under sustained development since the mid-2000s (cf., Lee 2012). Core areas for that research are Glacier National Park (central Rockies) and the Colorado Front Range (southern Rockies). High altitude ice patches and glaciers in the central Rocky Mountains of Wyoming and Montana have produced tree remains from long-abandoned tree-lines, residues of earlier, warmer climatic periods and wood and leather artifacts, including a $8400{ }^{14} \mathrm{C}$ cal BC dart (spear) fore-shaft found in association with butchered Bighorn sheep (Ovis canadensis) bone. Colorado Front Range discoveries of ice patch materials have been largely confined to ancient and abandoned timber-line tree remains and animal bone. Front Range ice patches above modern tree-line have produced skeletal bone from bison (Bison bison [skulls, a horn sheath, horn cores, teeth, a leg bone, a vertebra, and a partial scapula]), Bighorn sheep (Ovis Canadensis [a skull]), mule deer (Odocoileus hemionus [skeletal element descriptions remain unpublished]), and elk (Cervus elephas [antler tine]). Currently known ice patch fossils are dominated by bison skeletal elements, radiocarbon dated between $1588 \mathrm{cal}{ }^{14} \mathrm{C}$ cal $\mathrm{BC}$ and AD 1759 cal ${ }^{14} \mathrm{C}$ (Lee et al. 2006; Lee \& Benedict 2012: Table 1). No ice patch faunal remains identified to date show definitive evidence of human activity (e.g., butchering marks or associated hunting artifacts). However, carbon isotope and DNA analysis of ice patch bone, teeth, and antler promise to provide future knowledge about paleoecology, animal diet, and genetic variations between prehistoric and modern animal species (cf., Lee \& Benedict 2012: 44-45). A second form of ice patch evidence now emerging from the Colorado Front Range mountains are 
preserved subalpine tree remains above modern tree-lines that document past higher tree-lines and warmer climate. Two ice patch sites in Rocky Mountain National Park, discussed in the following section, contained subalpine spruce (Picea engelmanni) tree trunk sections radiocarbon dated to ca. $2390{ }^{14} \mathrm{C}$ cal $\mathrm{BC}$ which represent $70-80 \mathrm{~m}$ higher-than-modern tree-lines and termination of an earlier major warmer-than-present climatic episode (Benedict et al. 2008; Lee 2011; Lee \& Benedict 2012: 45, Table 2).

\section{Building Models of Prehistoric Natural and Archaeological Landscapes: An Example from Rocky Mountain National Park, USA}

University of Northern Colorado (UNC) researchers in Greeley, Colorado, USA, have conducted interdisciplinary studies since 1998 on Rocky Mountain National Park (RMNP) archaeology and long-term paleoclimate and paleoecological change. Over the past sixteen years, archaeological surface surveys by the university covered $121 \mathrm{~km}^{2}$ (12 098 hectares) of the park's total $1111 \mathrm{~km}^{2}$ (101 390 hectares) or $9.18 \%$ of its complete surface area. Those surveys documented 460 prehistoric and historic Native American sites and evidence for early human occupations dating from the region's earliest human cultural period, the Clovis culture (ca. $13200-12850$ cal ${ }^{14} \mathrm{C}$ BP $\left[{ }^{14} \mathrm{C}\right.$ calendar corrected chronology $]$ to removal of the park's most recent historic Native American inhabitants to government reservations in the late $19^{\text {th }}$ Century (Brunswig 2003, 2005, 2007, 2012).

There is now abundant evidence that: 1) interior mountain seasonal hunter-gatherer migratory transhumance patterns between low elevation mountain valleys and high elevation subalpine and alpine tundra ecological zones existed as early as the Clovis period (ca. $11200-10850{ }^{14} \mathrm{C}$ cal $\mathrm{BC} ; 2$ ) that those patterns were permanently established by early Late Paleoindian times (ca. 8 700-5 $800{ }^{14} \mathrm{C}$ cal BC), and 3 ) continued with few interruptions until historic times (Brunswig 2003, 2004, 2005, 2007, 2012). Those patterns of annual, seasonal transhumance over eleven millennia emphasized cool season (spring, fall, winter) residence in interior montane valleys adjacent to Rocky Mountain National Park, such as the Middle Park and North Park valleys, and warm season (late spring, summer and early fall) migrations to high elevation game foraging territories in the park's subalpine and alpine environmental zones (Brunswig 2004, 2005, 2007; Doerner \& Brunswig 2008; Brunswig et al. 2009, 2014a, 2014b). Adjoining North Park and Middle Park interior sedimentary basin valleys (elev. 2 500-2 $800 \mathrm{~m}$ ) where several larger herbivore species (e.g., bison-Bison bison, elk-Cervus canadensis, and Bighorn sheep-Ovis canadensis) and past hunter-gatherer bands spent cool season (fall-winter-spring) months con-

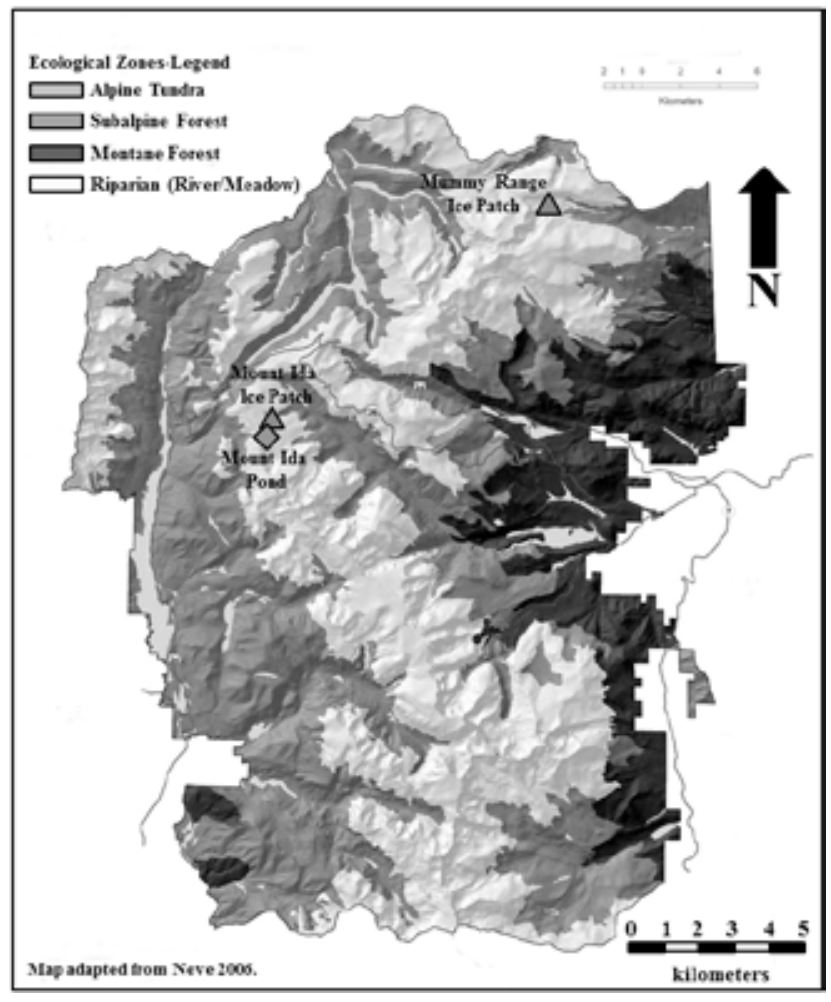

Figure 1. Computer map of ecological zones within Rocky Mountain National Park, Colorado, USA. Locations of two ice patches (Mummy Range and Mount Ida) and a tundra pond (Mount Ida Pond), discussed below, are shown on the figure. Above map adapted from Neve 2006

sist today of open sagebrush steppe with rolling hills, high linear ridge-lines, numerous artesian springs, and narrow river floodplains. Rocky Mountain National Park lies east and southeast of those valleys and is home to a $48 \mathrm{~km}$ long section of continental divide tundra ridgeline which enters the park at its northwest corner and exits at its central south boundary. Much of the park's 1600 hectares of alpine tundra and high elevation archaeological sites (game drives and hunting camps) are on or near the continental divide.

Ecological zones within the park, from lower to higher elevations are: 1) montane forests ( 2 226-2 $368 \mathrm{~m})$ which begin with ponderosa pine (Pinus ponderosa), then transition to Douglas Fir (Pseudotsuga menziesii) and include mixed stands of aspen (Populus tremuloides) and lodgepole pine (Pinus contorta); 2) subalpine forest ( 2 744-3 $507 \mathrm{~m}$ ) whose dominant tree species is Englemann spruce (Picea engelmanni); and 3) alpine tundra ( 3 507-4 $345 \mathrm{~m})$, exposed tree-less alpine grass and sedge meadows with rare low shrubs (primarily willow-Salix arctica) in wind-protected areas. Upper tree-line is defined as continuous, symmetrical forest with mature trees averaging $3 \mathrm{~m}$ or more in height (Benedict et al. 2008; Körner 2012: 198-199). In 


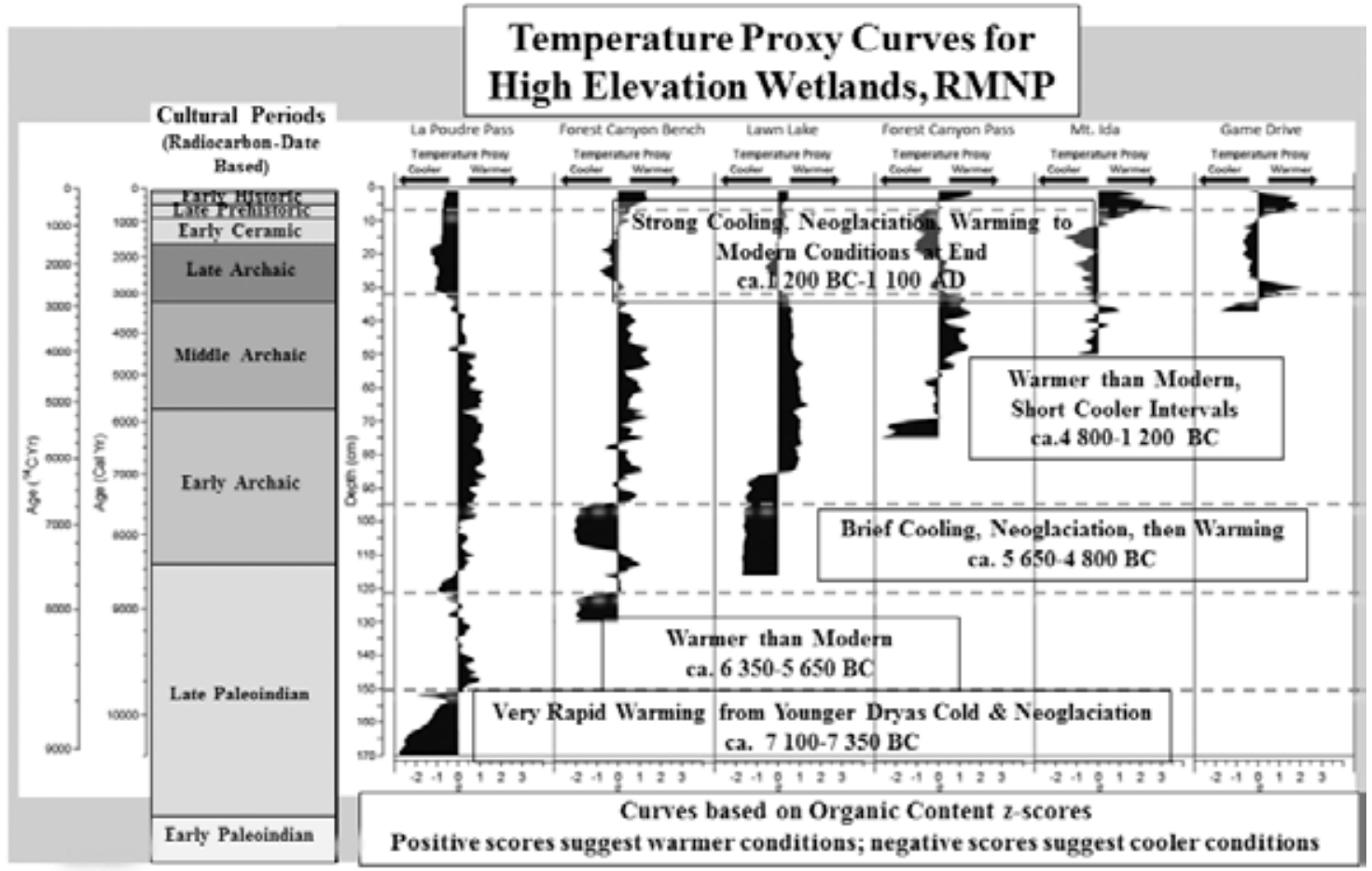

Figure 2. Chart showing $10300{ }^{14} \mathrm{C}$ cal years of temperature-based climate patterns (warmer to cooler than present day) from six high-elevation wetland (bogs and fens) sites in Rocky Mountain National Park, USA. The "cultural periods" column on the left shows age ranges of successive regional archaeological periods in their ${ }^{14} \mathrm{C}$ cal based chronology

many locations, continuous subalpine forest is separated from alpine tundra by continuous or dispersed stands of dwarfed spruce and fir trees and shrubs (krummholz), a transitional zone known as alpine-subalpine ecotone (edge boundary). Riparian floodplains and meadows occur in the lower (montane through subalpine) ecological zones. Figure 1 shows elevational distributions of the above ecological zones within Rocky Mountain National Park.

This past year (2014), University of Northern Colorado researchers, including the author, completed an early stage interdisciplinary study of climate change which included reconstruction of past upper subalpine forest treeline changes and human occupation histories represented by archaeological sites which were once part of the above described human-animal seasonal transhumance system (Brunswig et al. 2014a, 2014b). Our study used climate proxy data from stratified radiocarbon-dated sediments from fourteen bogs, ponds, and lakes in the park, most from subalpine and alpine ecological zones (cf., Elias 1983, 1985, 1988, 1991, 1996, 2001; Elias et al. 1986; Short 1985; Reasoner \& Jodry 2000; Doerner 2005, 2007, 2008; Doerner \& Brunswig 2008; Brunswig et al. 2009, Brunswig et al. 2014a, 2014b). Paleoclimate and paleoecology conditions from the Late Pleistocene to the early historic era were reconstructed through analysis of cored sed- iments for magnetic susceptibility, organic content, bulk density (sediment size and composition), and plant pollen (Brunswig et al. 2014a: 15-19, 2014b: 277-279). Individually and together, these types of data provide information on changes in temperature, moisture, and ecological conditions from the present day along radiocarbon-dated timelines extending to the last major ice age. Figure 2 shows reconstructed past climate temperature patterns from ca. 8 $400{ }^{14} \mathrm{C}$ cal BC years to the present, based on organic content data from several high elevation research sites.

In high altitude mountain ranges such as the North American Rockies, climate change, predominantly as longer-term seasonal temperature patterns, often significantly affects upper subalpine forest tree-lines, causing them to drop or rise in elevation with persistent trends in increasing warmth or cold (Tranquillini 1979; Lloyd \& Graumlich 1997: 1205-1207). Identifying past tree-lines is a difficult task. In North America's western mountains, former tree-lines above modern boundaries can be inferred through three types of evidence: tree remains preserved: 1) as desiccated wood in high arid tundra, 2) buried in anaerobic bog, fen, or pond peat, or 3) within long-frozen ice patches. As discussed earlier, central and southern Rocky Mountain ice patches, compacted snow, partially melted and repeatedly refrozen in mountain hollows and 


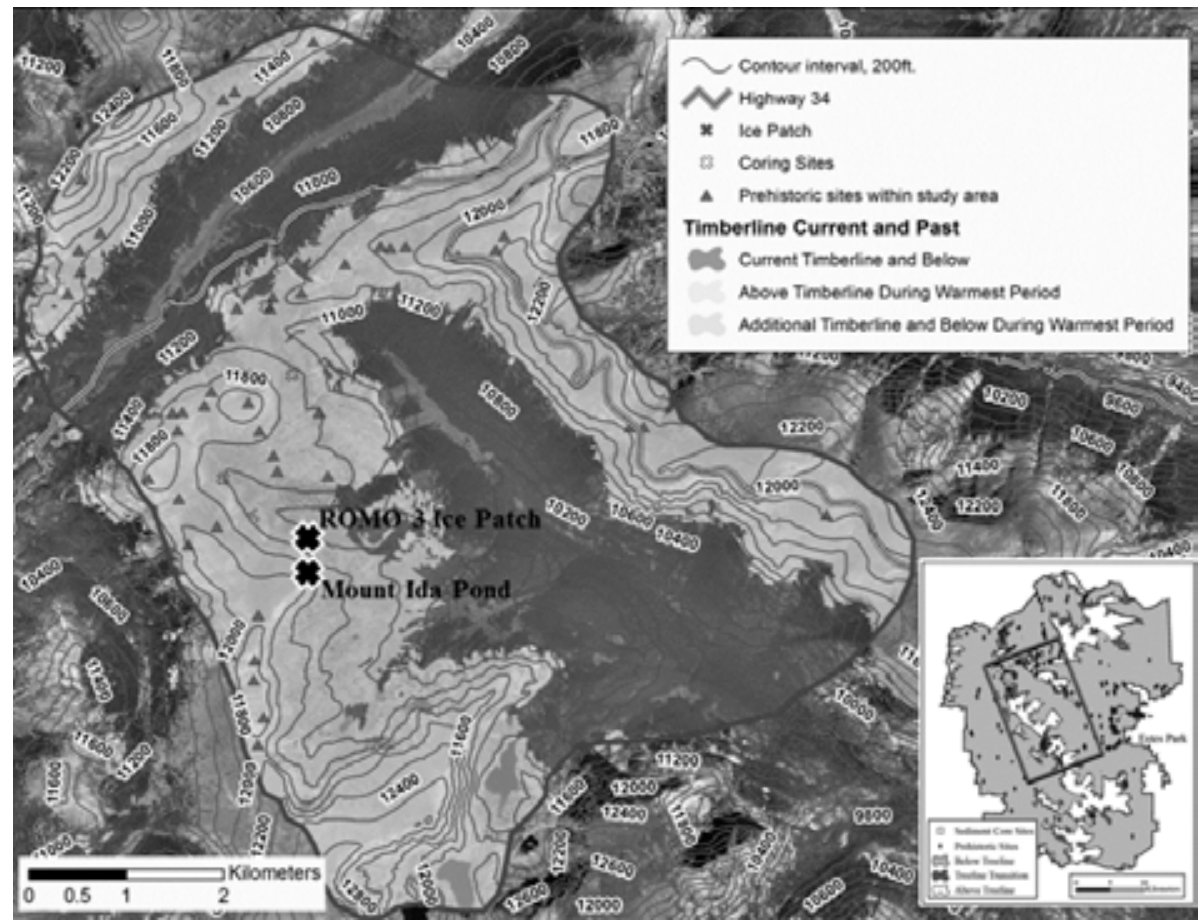

Figure 3. Map showing a University of Northern Colorado GIS paleoclimate modeling area (outlined with a dark gray border) within Rocky Mountain National Park. The area's location in the park is shown by an inset map at the lower right-hand corner. Locations of the ROMO 3 ice patch and Mount Ida Pond, discussed in text, are marked by black Xs

protected slopes, persisted for hundreds and even thousands of years, often containing organic artifacts (leather and wood), preserved trees, and animal bone, some of the latter having been hunted and butchered by prehistoric hunters (Lee et al. 2006; Benedict et al. 2008; Lee 2010, 2012; Lee \& Benedict 2012;). Two ice patches recently studied in northern and central areas of Rocky Mountain National Park contain spruce tree trunks radiocarbon-dated between 2355 and $2299{ }^{14} \mathrm{C}$ cal BC which document that period's upper tree-line boundary 50-70 $\mathrm{m}$ higher than today's tree-line (Benedict et al. 2008; Lee 2011; Lee \& Benedict 2012). One of the ice patches (ROMO 3) contains spruce tree trunk remains whose outer rings were radiocarbon-dated to $2299{ }^{14} \mathrm{C}$ cal BC, lies at $3487 \mathrm{~m}, 70 \mathrm{~m}$ above present-day tree-line, within a Geographic Information System (GIS) "extracted" research area in the center of Rocky Mountain National Park (Fig. 3).

A second source of past tree-line evidence in our designated study area was recovered by a University of Colorado researcher three decades earlier from 40-50 cm deep alpine tundra pond ( $3450 \mathrm{~m}$ ) sediments as pollen, organic tree parts, and insect remains (Elias 1985: 33, 1991: Table 2). The pond is located on the east slope of the continental divide ridgeline above and south of the ROMO 3 ice patch. Analysis of its pollen, spruce cones, conifer (likely spruce) needles, and fossil insect parts existed at $\sim 130 \mathrm{~m}$ above modern subalpine forest tree-line between 8185 and $7378{ }^{14} \mathrm{C}$ cal BC (Elias 1985: 33, 35-36, 43-45). The ROMO 3 ice patch and Mount Ida Pond sites document two specific tree-line boundary elevations and dates for our study area. The study area shown in Figure 3 covers $46.93 \mathrm{~km}^{2}$. Seventy per cent of its usable surface (excluding rock outcrops, steep slopes in excess of $50^{\circ}$, and sheer cliff walls) has been archaeologically surveyed. Eighty-six prehistoric sites have been recorded within its two main ecological zones (alpine-subalpine ecotone and alpine tundra). Occupation periods, based on the presence of known regional chronology projectile point types, are documented for twenty-three sites. Figure 4 illustrates calendar (calibrated) age radiocarbon-date defined time periods of the region's archaeological (cultural) periods.

The study area contains two major hunting game drives along its continental divide tundra ridgeline along with several nearby game processing (butchering and stone tool repair) sites. Several camps, used as support camps for the alpine game drives, are located in a large open pass in alpine-subalpine ecotone at the study area's northwest end. Many sites are hypothesized to have once been part of a local hunting system of tundra game drives with low built "game-funnel" walls, rock-wall and shallowly excavated and loose rock wall hunting blinds, often using natural concealment such as large boulders. The animals hunted 


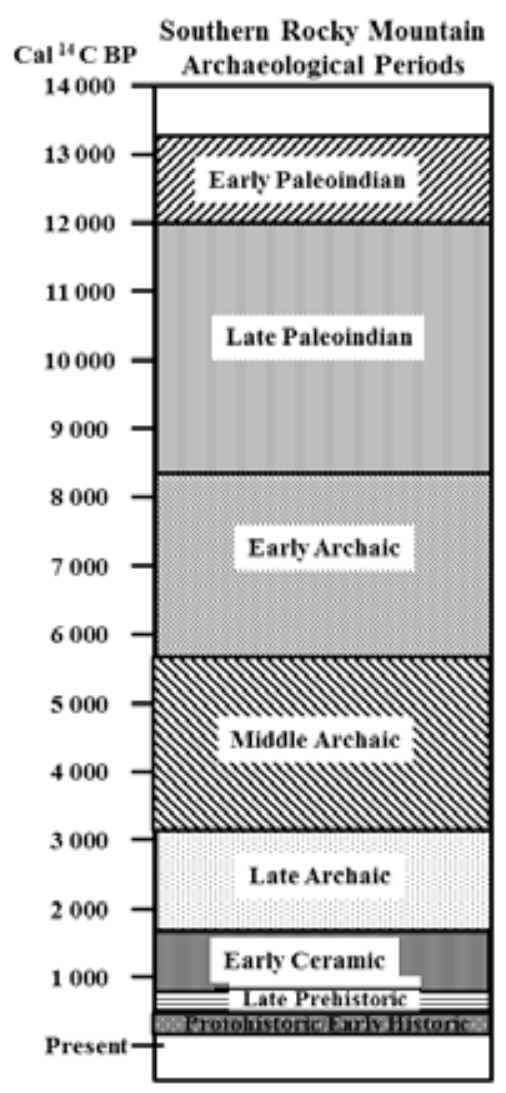

Figure 4. Chart of successive regional archaeology/cultural periods showing each period's radiocarbon-based calendar (calibrated) chronology

were big horn sheep and elk which grazed on high tundra grasslands in the mid-summer warm season. Smaller specialized (secondary) camps or work areas located near the game drives supported after-hunt butchering, skinning, and carcass dismemberment for the transport of hides and animal meat parts (legs, rib sections, etc.) to lower elevation base camps in the alpine-subalpine ecotone for advanced processing and meat preservation (drying, smoking...).

Combining evidence from radiocarbon-dated pond and wet fen sediment cores and the single ice-patch tree remains, a provisional model of tree-line, climate, and ecological zones changes can be proposed, changes which can be integrated with the archaeological land use (settlement) patterns through time. Five successive chronological periods, $11200-10850{ }^{14} \mathrm{C}$ cal BC, $8700-6300{ }^{14} \mathrm{C}$ cal BC, $6300-3700{ }^{14} \mathrm{C}$ cal BC, $3700{ }^{14} \mathrm{C}$ cal BC-500 ${ }^{14} \mathrm{C}$ cal $\mathrm{AD}$, and $500-1870{ }^{14} \mathrm{C}$ cal $\mathrm{AD}$, can be climatically and archaeologically defined (Table 1).

The latest Pleistocene was characterized by a very limited human presence, in the form of Clovis hunters (11 200$10850{ }^{14} \mathrm{C}$ cal BC), in the study area and a cold but ameliorating (warming) late glacial climate. Tree-lines, based on glacial geology studies in the region, are estimated to have been $\sim 300 \mathrm{~m}$ below modern-day boundaries. Good climate data for the succeeding chronological interval, 10 850-8 $700{ }^{14} \mathrm{C}$ cal BC, time range of the colder neo-glacial Younger Dryas climatic episode, is missing from all but one of the above described park sediment cores, that of at Sky Pond, only a few kilometers southeast of the study area (cf., Menounos \& Reasoner 1997; Reasoner \& Jodry 2000). However, Sky Pond core sediments and earliest Holocene glacial moraines in the park and region document intense cold phase and renewed cirque glacier expansion (Satanta Peak Neoglacial Stade) during the Younger Dryas time interval. Archaeological evidence for a parallel Folsom cultural period occupation during the Younger Dryas is virtually absent from high altitude alpine, alpine-subalpine ecotone and subalpine ecological zones although Folsom sites occur in lower elevation, interior mountain valleys to the west and northwest (Brunswig 2007; Surovell \& Waguespack 2007; Waguespack \& Surovell 2014). It now appears Folsom use of high altitude tundra was non-existent due to shortened growing seasons, extreme summer cold, and year-round persistent snow fields which would have limited summer herbivore (game animal) grazing and hunting. Dramatic, rapid warming at the end of the Younger Dryas (ca. 9550 ${ }^{14} \mathrm{C}$ cal BC) resulted in a rise in tree-line to $\sim 130 \mathrm{~m}$ above modern parameters by $8875{ }^{14} \mathrm{C}$ cal $\mathrm{BC}$ and establishment of tundra game drives by early Late Paleoindian hunters along the continental divide within the study area. Treeline briefly dropped and summer temperatures cooled with regional, modest re-glaciation between ca. 5650 and 4800 ${ }^{14} \mathrm{C}$ cal $\mathrm{BC}$ followed by an extended $\left(6300-3700{ }^{14} \mathrm{C}\right.$ cal $\mathrm{BC}$ ) series of warm and slightly cooler climate intervals (the Altithermal Episode) associated with the Early Archaic cultural period. Seasonal transhumance to tundra game drives by hunting groups based in interior mountain valleys and eastern Front Range mountain foothills during fall through spring months was consistently in operation throughout the Early Archaic. Sediment and ice patch data show termination of extended, warm Altithermal climate by 3700 ${ }^{14} \mathrm{C}$ cal BC when Mount Ida ice patch tree remains place subalpine forest tree-line at $\sim 70-80 \mathrm{~m}$ above-present, but declining with on-going significant cooling and renewed neo-glaciation. Cool climate and periodic neo-glacial advances continued from $3700{ }^{14} \mathrm{C}$ cal $\mathrm{BC}$ through $500{ }^{14} \mathrm{C}$ cal $\mathrm{AD}$, but gradual warming began by ca. $100{ }^{14} \mathrm{C}$ cal $\mathrm{AD}$ and modern-era climate and tree-line conditions, with periodic upward /downward shifts of tree-line on the order $\pm 5-10 \mathrm{~m}$ until $1870 \mathrm{AD}$, were established. There is evidence that Native American tundra game hunting and seasonal lowland-highland transhumance continued throughout multiple cooling and warming episodes from ca. $3700{ }^{14} \mathrm{C}$ cal BC- $1870{ }^{14} \mathrm{C}$ cal AD although high altitude game drives may have been temporarily abandoned during some short periods of more intense cooling and neo-glacial advances (cf., Benedict 1999). 
Table 1. Extrapolated chronological periods of climate and tree-line change and archaeological periods and landscape use patterns in the RMNP study area

\begin{tabular}{|c|c|c|}
\hline $\begin{array}{c}\text { Chronology } \\
\left({ }^{14} \mathrm{C} \text { cal BC/AD }\right)\end{array}$ & Archaeology & $\begin{array}{c}\text { Climate/Treeline } \\
\text { (below/above present day) }\end{array}$ \\
\hline $11200-10850 \mathrm{BC}$ & $\begin{array}{c}\text { Early Paleoindian Period } \\
\text { (Clovis), Surface Spear } \\
\text { Points-No Sites }\end{array}$ & $\begin{array}{l}\text { Cold, Late Glacial, } \\
\text { Treeline } \sim 300 \text { m Below }\end{array}$ \\
\hline $8700-6300 \mathrm{BC}$ & $\begin{array}{c}\text { Late Paleoindian Period, } \\
\text { Game Drives, Camps, } \\
\text { Transhumance }\end{array}$ & $\begin{array}{c}\text { Abrupt Warming, } \\
\text { Later Cooling, } \\
\text { Max. Treeline } \sim 130 \mathrm{~m} \text { Above }\end{array}$ \\
\hline $6300-3700 \mathrm{BC}$ & $\begin{array}{l}\text { Early Archaic, Game Drives, } \\
\text { Camps, Transhumance }\end{array}$ & $\begin{array}{c}\text { Warm, } \\
\text { Treeline } \sim 70-80 \mathrm{~m} \text { Above }\end{array}$ \\
\hline $3700 \mathrm{BC}-500 \mathrm{AD}$ & $\begin{array}{l}\text { Mid Archaic/early Early } \\
\text { Ceramic, Game Drives, } \\
\text { Camps, Transhumance }\end{array}$ & $\begin{array}{l}\text { Cool, Neoglaciation, } \\
\text { Treeline } \sim 50-70 \mathrm{~m} \text { Below }\end{array}$ \\
\hline 500-1870 AD & $\begin{array}{l}\text { Late Early Ceramic/early } \\
\text { Historic, Game Drives, } \\
\text { Camps, Transhumance }\end{array}$ & $\begin{array}{l}\text { Modern Climate \& } \\
\text { Treeline }( \pm 5-10 \mathrm{~m})\end{array}$ \\
\hline
\end{tabular}

\section{Realizing the Potential of Ice Patch Archaeology}

Global warming will, for the foreseeable future, continue to degrade and destroy earth's mountain ice patches and glaciers. Both organic natural and cultural materials will be at risk as they are exposed and deteriorate unless they are located and studied for their intrinsic evidence of past human activities and climatic-ecological change. As shown by the North American Rocky Mountain National Park case study and earlier examples from Europe and North America, ice patch and glacier evidence may, when analyzed with interdisciplinary research methods, produce new avenues of understanding of past human and natural systems. While the pace of global warming will undoubtedly exceed our ability to fully recover emerging (and disappearing) ice patch and glacier evidence, ice patch archaeologists and natural scientists are developing new methods of detecting and monitoring melting ice and snow features around the world. In Rocky Mountain National Park, researcher Craig Lee utilized multiple year satellite imagery from GoogleEarth ${ }^{\mathrm{TM}}$ to identify locations of ice patches and climate-induced changes (melting) in their physical footprints (Lee 2011). Lee and others (Lee 2012) are actively conducting formal ice patch survey and monitoring programs in North America's central and southern Rocky Mountains. Canada's long-term Northwest Territories Ice Patch Study project is providing a similar effort for North America's far northern hemisphere (Andrews et al. 2009; Andrews \& MacKay 2012). In Europe's Alps, researchers have re- cently described a computer modeling software program, GlaciArch, now being used in the Pennine Alps, which has already provided a preliminary "forecast of a 93\% loss in [glacial surface] area by 2090" and which its creators recommend be used to provide "immediate focus...to high archaeological potential areas in hopes to locate and recover possibly irreplaceable, culturally significant items...in order to protect and conserve these exceptional and rare relics..." (Rogers et al. 2014: 10). Many academic and government-based scientific organizations correlate and report satellite and ground-based research data on advancing changes in the world's glaciers and ice sheets, highly useful in identifying and tracking disappearing glaciers and ice patches for investigation (Kääb et al. 2002; Knoll \& Kerschner 2009; Lambers \& Zingman 2012; National Snow and Ice Data Center 2014). With advanced new methods in detecting and monitoring the world's melting ice features and systematic programs of scientific survey and analysis of emerging products of those features, we are poised to learn more about our past as our global-warming future unfolds.

\section{Acknowledgments}

Study was partly supported by research fellowship within project "Enhancing Educational Potential of Nicolaus Copernicus University in the Disciplines of Mathematical and Natural Sciences" (project no. POKL.04.01.01-00081/10). 


\section{References}

Alix C., Hare P. G., Andrews T. D. \& MacKay G., 2012, A thousand years of lost hunting arrows: Wood analysis of ice patch remains in northwestern Canada, Arctic 65 (Supplement 1): 95-117.

Andrews T. D. \& MacKay G., 2012, The Archaeology and Paleoecology of Alpine Ice Patches: a global perspective, Arctic 65 (Supplement 1): iii-vi.

Andrews T. D., MacKay G. \& Andrews L., 2009, Hunters of the Alpine Ice: The NWT Ice Patch Study, Prince of Wales Northern Heritage Centre, Education, Culture and Employment, Government of the Northwest Territories, Yellowknife, Canada.

Andrews T. D., MacKay G. \& Andrews L., 2012a, Archaeological investigations of alpine ice patches in the Selwyn Mountains, Northwest Territories, Canada, Arctic 65(Supplement 1): 1 -21.

Andrews T. D., MacKay G., Andrew L., Stephenson W., Barker A., Alix C. \& et al., 2012b, Alpine ice patches and Shu'htagot'ine land use in the Mackenzie and Selwyn Mountains, Northwest Territories, Canada, Arctic 65(1): 22-42.

Benedict J. B., 1999, Effects of changing climate on game-animal and human use of the Colorado High Country (U.S.A.) since 1000 BC, Arctic, Antarctic, and Alpine Research 31(1): 1-15.

Benedict J. B., Benedict R. J. \& Lee C. M., 2008, Spruce Trees from a Melting Ice Patch: evidence for Holocene climatic change in the Colorado Rocky Mountains, U.S.A., The Holocene 18(7): 1067-1076.

Bortenschlager S. \& Oeggl K., 2000, The Iceman and his natural environment: palaeobotanical results. SpringerVerlag, Wien and New York.

Brunswig R. H., 2003, Clovis-Age Artifacts from Rocky Mountain National Park and Vicinity, North Central Colorado, Current Research in the Pleistocene 20: 7-9.

Brunswig R. H., 2004, Hunting Systems and Seasonal Migratory Patterns through Time in Rocky Mountain National Park, [in:] R. H. Brunswig, W. B. Butler (eds), Ancient and Historic Lifeways of North America's Rocky Mountains: Proceedings of the 2003 Rocky Mountain Anthropological Conference, Department of Anthropology, University of Northern Colorado, Greeley: 392-410.

Brunswig R. H., 2005, Prehistoric, Protohistoric, and Early Historic Native American Archeology of Rocky Mountain National Park: Final Report of Systemwide Archeological Inventory Program Investigations by the University of Northern Colorado (1998-2002), Department of Anthropology, University of Northern Colorado, Greeley, Report submitted to Rocky Mountain National Park, National Park Service, Estes Park.
Brunswig R. H., 2007, Paleoindian Cultural Landscapes and Archaeology of North Central Colorado's Southern Rockies, [in:] R. H. Brunswig, B. L. Pitblado (eds), Frontiers in Colorado Paleoindian Archaeology: From the Dent Site to the Rocky Mountains, University Press of Colorado, Boulder: 261-310.

Brunswig R. H., 2012, Apachean Archaeology of Rocky Mountain National Park, Colorado, and the Colorado Front Range, [in:] D. Seymour (ed.), From the Land of Ever Winter to the American Southwest: Athapaskan Migrations, Mobility, and Ethnogenesis, University of Utah Press, Salt Lake City, Utah: 20-36.

Brunswig R. H., Doerner J. \& Diggs D., 2014a, Phase 1 GIS Mapping of Cultural, Paleoclimatic and Paleoenvironmental Landscapes in Rocky Mountain National Park: Report to Rocky Mountain National Park, National Park Service, Departments of Anthropology and Geography \& GIS, University of Northern Colorado, Greeley, Colorado.

Brunswig R. H., Doerner J. \& Diggs D., 2014b, Eleven Millennia of Human Adaptation in Colorado's High Country: Modeling Cultural and Climatic Change in the Southern Rocky Mountains, [in:] S. Kulyk, C. G. Tremain, M. Sawyer (eds), Climates of Change: The Shifting Environments of Archaeology, University of Calgary, Chacmool Archaeological Association, Calgary, Canada: 273-286.

Brunswig R. H., Doerner J. P., Diggs D., Connor J., Benton L. \& Edwards K., 2009, Report on a Pilot Study for Investigations into Cultural-Natural Landscapes and Ecological Patch Islands in Forest Canyon Pass, Rocky Mountain National Park, Department of Anthropology, University of Northern Colorado, Greeley, Report submitted to Rocky Mountain National Park, National Park Service, Estes Park.

Callanan M., 2012, Central Norwegian Snow Patch Archaeology: patterns past and present, Arctic 65: 178188.

Callanan M., 2013, Melting snow patches reveal Neolithic archery, Antiquity 87: 728-745.

Doerner J. P., 2005, A High-Resolution Paleotemperature Record from Poudre Pass Fen, Rocky Mountain National Park, USA, Department of Geography, University of Northern Colorado, Greeley.

Doerner J. P., 2007, Late Quaternary Prehistoric Environments of the Colorado Front Range, [in:] R. H. Brunswig, B. L. Pitblado (eds), Frontiers in Colorado Paleoindian Archaeology: From the Dent Site to the Rocky Mountains, University Press of Colorado, Boulder: 11-38.

Doerner J. P., 2008, Holocene Fire History and Climate Change in Rocky Mountain National Park: Pollen and Charcoal Evidence from Bear Lake, Department of Geography, University of Northern Colorado, Greeley, 
Report submitted to Rocky Mountain National Park, National Park Service, Estes Park.

Doerner J. P. \& Brunswig R. H., 2008, Modeling Paleoenvironmental and Archeological Landscapes of Ancient Game Drive Systems in Rocky Mountain National Park, North Central Colorado, Departments of Anthropology and Geography, University of Northern Colorado, Greeley, Report submitted to Rocky Mountain National Park, National Park Service, Estes Park.

Elias S. A., 1983, Paleoenvironmental Interpretations of Holocene Insect Fossil Assemblages from the La Poudre Pass Site, Northern Colorado Front Range, Palaeogeography, Palaeoclimatology, Palaeoecology 41: 87-102.

Elias S. A., 1985, Paleoenvironmental Interpretations of Holocene Insect Fossil Assemblages from Four High-Altitude Sites in the Front Range, Colorado, U.S.A., Arctic and Alpine Research 7(1): 31-48.

Elias S. A., 1988, Late Pleistocene Paleoenvironmental Studies from the Rocky Mountain Region: A Comparison of Pollen and Insect Fossil Records, Geoarchaeology 3(2): 147-153.

Elias S. A., 1991, Insects and Climate Change: Fossil Evidence from the Rocky Mountains, Bioscience 41(8): 552-559.

Elias S. A., 1996, Late Pleistocene and Holocene seasonal temperatures reconstructed from fossil beetle assemblages in the Rocky Mountains, Quaternary Research 46: 311-318.

Elias S. A., 2001, Paleoecology and Late Quaternary Environments of the Colorado Rockies. [in:] W. D. Bowman, T. R. Seastedt (eds.), Structure and Function of an Alpine Ecosystem, Oxford University Press, New York: 285-303.

Elias S. A., Short S. K. \& Clark P. U., 1986, Paleoenvironmental Interpretations of the Late Holocene, Rocky Mountain National Park, Colorado U.S.A, Revue de Paleobiologie 5(1): 127-142.

Ermini L., Olivieri C., Rizzi E., Corti G., Bonnal R., Soares P., Luciani S., Marota I., De Bellis G., Richards M. B. \& Rollo F., 2008, Complete mitochondrial genome sequence of the Tyrolean Iceman, Current Biology 18: 1687-1693.

Farnell R., Hale P. G., Blake E., Bowyer V., Schweger C., Greer S. \& et al., 2004, Multidisciplinary investigations of alpine ice patches in southwest Yukon, Canada: paleoenvironmental and paleobiological investigations, Arctic 57(3): 247-259.

Galloway J. M., Adamczewski J., Schock D. M., Andrews T. D., MacKay G., Bowyer V. E. \& et al., 2012, Diet and habitat of mountain woodland caribou inferred from dung preserved in 5000-year-old alpine ice in the Selwyn Mountains, Northwest Territories, Canada, Arctic 65(1): 59-79.
Grosjean M., Suter P. J., Trachsel M. \& Wanner H., 2007, Ice-borne prehistoric finds in the Swiss Alps reflect Holocene glacier fluctuations, Journal of Quaternary Science 22(3): 203-207.

Hafner A., 2012, Archaeological discoveries on Schnidejoch and at other ice sites in the European Alps, Arctic 65 (Supplement 1): 189-202.

Hare P. G., Greer S., Gotthardt R., Farnell R., Bowyer V., Schweger C. \& Strand D., 2004, Ethnographic and archaeological investigations of alpine ice patches in southwest Yukon, Canada, Arctic 57(3): 260-272.

Hare P. G., Thomas C. D., Topper T. N. \& Gotthardt R. M., 2012, The Archaeology of Yukon Ice Patches: new artifacts, observations, and insights, Arctic 65: 118-135.

Ion P. G. \& Kershaw G. P., 1989, The selection of snowpatches as relief habitat by woodland caribou (Rangifer tarandus caribou), Macmillan Pass, Selwyn/Mackenzie Mountains, N.W.T., Canada, Arctic and Alpine Research 21(2): 203 -211.

Jacob T., Wahr J., Pfeffer W.T. \& Swenson S., 2012, Recent contributions of glaciers and ice caps to sea level rise, Nature 482(7386): 514-518.

Kääb A., Paul F., Maisch M., Hoelzle M. \& Haeberli W., 2002, The new remote sensing derived Swiss glacier inventory: II. first results, Annals of Glaciology 34: 362-366.

Keen J. M., 2008, Bodies from the Ice: melting glaciers and the recovery of the past, Houghton Mifflin Company, Boston.

Khan S. A., Kjaer K. H., Bevis M., Bamber J. L., Wahr J., Kjeldsen K. K., Bjork A. A., Korsgaard N. J., Stearns L. A., van den Broeke M. R., Liu L., Larsen N. K. \& Muresan I. S., 2014, Sustained mass loss of the northeast Greenland ice sheet triggered by regional warming, Nature Climate Change 4(4): 292-299.

Knoll C. \& Kerschner H., 2009, A glacier inventory for South Tyrol, Italy, based on airborne laser-scanner data, Annals of Glaciology 50(53): 46-52.

Körner C., 2012, Treelines will be understood once the functional difference between a tree and a shrub is, Ambio 41(3): 197-206.

Kutschera W., 1994, Radiocarbon dating of the Iceman Ö'tzi with accelerator mass spectrometry, Radiocarbon 36(2): 1-9.

Kuzyk G. W., Russell D. E., Farnell R. S., Gotthardt R. M., Hare P. G. \& Blake E., 1999, In pursuit of prehistoric caribou on Thandlät, southern Yukon, Arctic 52(2): 214-219.

Lambers K. \& Zingman I., 2012, Towards detection of archaeological objects in high-resolution remotely sensed images: the Silvretta case study, [in:] Proceedings of the 40th Conference in Computer Applications and Quantitative Methods in Archaeology, Southampton, United Kingdom, Southhampton, England: 1-11. 
Lee C. M., 2010, Global warming reveals wooden artefact frozen over 10000 years ago in the Rocky Mountains, Antiquity 84(325).

Lee C. M., 2011, Current Status of Ice Patch Surveys in Rocky Mountain National Park, 2010 Investigator's Annual Report, Rocky Mountain National Park, National Park Service, Arctic and Alpine Institute, University of Colorado, Boulder.

Lee C. M., 2012, Withering snow and ice in the mid-latitudes: a new archaeological and paleobiological record for the Rocky Mountain Region, Arctic 65(1): 165-177.

Lee C. M. \& Benedict J., 2012, Ice bison, frozen forests and the search for archaeology in Colorado Front Range ice patches, Colorado Archaeology 78 (1): 41-53.

Lee C. M., Benedict J. \& Lee L. B., 2006, Ice patches and remnant glaciers: paleontological and archeological possibilities in the Colorado high country, Southwestern Lore 72: 26-41.

Lloyd A. H. \& Graumlich L. J., 1997, Holocene dynamics of treeline forests in the Sierra Nevada, Ecology 78(4): 1199-1210.

Magny M. \& Haas J. H., 2004, A major widespread climatic change around $5300 \mathrm{cal}$. yr BP at the time of the Alpine Iceman, Journal of Quaternary Science 19(5): 423-430.

Menounos B. \& Reasoner M. A., 1997, Evidence for cirque glaciation in the Colorado Front Range during the Younger Dryas Chronozone, Quaternary Research 48: 38-47.

Meulendyk, T., Moorman, B. J., Andrews, T. D. \& MacKay, G., 2012, Morphology and development of ice patches in Northwest Territories, Canada, Arctic 65(1): 43-58.

National Academy of Sciences, 2014, Climate Change Evidence \& Causes: an Overview from the Royal Society and U.S. National Academy of Sciences, U.S. National Academy of Sciences, Washington, D.C.

National Snow and Ice Data Center, 2014, World Glacier Inventory Database, University of Colorado, Boulder, http://nsidc.org/data/docs/noaa/g01130_glacier_inventory/ [Accessed: 27.10.2014].

Neve L. A., 2006, Soil Survey of Rocky Mountain National Park, Colorado, National Resources Conservation Service, Department of Agriculture, Denver, Colorado.

Oeggl K., 2009, The significance of the Tyrolean Iceman for the archaeobotany of Central Europe, Vegetation History and Archaeobotany 18: 1-11.

Radic V. \& Hock R., 2011, Regionally differentiated contribution of mountain glaciers and ice caps to future sea-level rise, Nature Geoscience 4: 91-94.

Reasoner M. A. \& Jodry M. A., 2000, Rapid response of alpine timberline vegetation to the Younger Dryas climate oscillation in the Colorado Rocky Mountains, USA, Geology 28(1): 51-54.
Reckin R., 2013, Ice patch archaeology in global perspective: archaeological discoveries from alpine ice patches worldwide and their relationship with paleoclimates, Journal of World Prehistory 26: 323-385.

Rogers S. R., Fischer M. \& Huss M., 2014, Combining glaciological and archaeological methods for gauging glacial archaeological potential, Journal of Archaeological Science doi: 10.1016/j.jas.2014.09.010.

Rollo F., Ubaldi M. Ermini L. \& Marota I., 2002, Ötzi's last meals: DNA analysis of the intestinal content of the Neolithic glacier mummy from the Alps, Proceedings of the National Academy of Sciences of the United States of America 99(20): 12594-12599.

Short S. K., 1985, Palynology of Holocene sediments, Colorado Front Range: vegetation and treeline changes in the subalpine forest, American Association of Stratigraphic Palynologists Contribution Series 16: 7-30.

Spindler K., 1993, The Man in the Ice: the Discovery of a 5,000 year-old body reveals the secrets of the Stone Age, Harmony Books, New York.

Spindler K., 1995, L'homme du glacier: une momie du glacier du Hauslabjoch vielle de 5,000 ans dans les Alpes de l'Özzal, L'Anthropologie 99(1): 104-114.

Surovell T. A. \& Waguespack N. M., 2007, Folsom hearth-centered use of space at Barger Gulch, Locality B, [in:] R. H. Brunswig, B. L. Pitblado (eds) Frontiers in Colorado Paleoindian Archaeology: From the Dent Site to the Rocky Mountains, University Press of Colorado, Boulder: 218-259.

Suter P. J., Hafner A. \& Glauser K., 2005, Lenk-Schnidjoch. Funde aus dem Eis-ein vor- und frühgeschichtlicher Passübergang, Archäologie im Kanton Bern 6B: 499-522.

Tranquillini, W., 1979, Physiological ecology of the alpine timberline, Ecological Studies 31: 119-131.

Vanzetti A., Vidale M., Gallinaro M., Frayer D. W. \& Bobdioli L., 2010, The Iceman as burial, Antiquity 84: 681-692.

Vedeler M. \& Jørgensen L. B., 2013, Out of the Norwegian glaciers: Lendbreen-a tunic from the early first millennium AD, Antiquity 87: 788-801.

Waguespack N. M. \& Surovell T. A., 2014, A simple method for identifying households using lithic assemblages: a case study from a Folsom campsite in Middle Park, Colorado, [in:] D. H. MacDonald, W. Andrefsky Jr., P.L. Yu (eds.) Lithics in the West, University of Montana Press, Missoula: 35-49.

zur Nedden D., Wicke K., Knapp R., Siedler H., Wilfing H., Weber G. \& et al., 1994, New findings on the Tyrolean 'Ice Man': Archaeological and CT-body analysis suggest personal disaster before death, Journal of Archaeological Science 21: 809-818. 